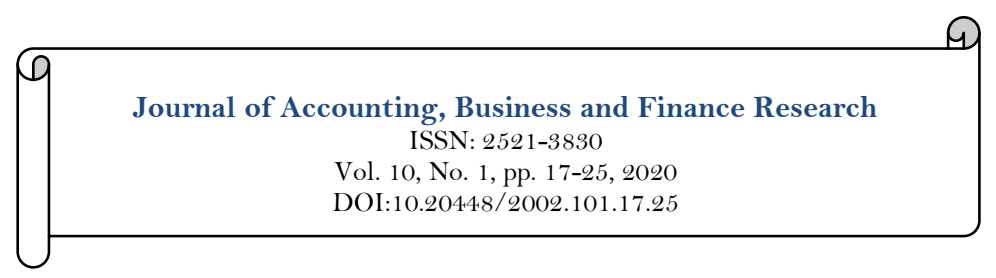

\title{
The Finance-Growth Nexus: An Empirical Analysis from Brazil
}

\author{
Francisco Marques ${ }^{1}$ \\ Patricia Almeida ${ }^{2}$ \\ Marcia Silva ${ }^{3}$ \\ ${ }^{1,2, s}$ Mackenzie Presbyterian University, Brazil. \\ Email:pat.almei@mackenzie.br
}

\section{Abstract}

$A$ well-established financial system is very crucial for the economic growth and development of any country. There are many aspects that are studied in relation with financial development such as savings, investments, and technical innovations etc. which affect the growth of economy in a country in one way or the other. In this context, the researcher has designed this study to explore the relationship amid financial development and economic growth of Brazil, which is clear from the title of the study i.e. finance-growth nexus. In continuation of this objective, the researcher has collected data from Brazil and the collected data is time series. The period for which the data has been gathered comprises of 30 years and has been collected from the most authentic sources of data or databases such as World Bank Development. The collected data has been analyzed by applying the techniques such as unit root, bounds test and ARDL estimation. These results indicate that private credit has noteworthy along with positive impact on economic growth. The next result of the study suggests that gross domestic saving does not pose any momentous impact on the economic growth of the country. The impact of trade openness has been found as significant along with negative in Brazil. The inflation has significant but negative impact on economic growth in longer run but this impact is insignificant in shorter run.
Keywords:

Private credit

Gross domestic saving

Trade openness

inflation

Economic growth

ARDL estimation

Brazil, Finance-growth nexus $(F G N)$.

Licensed:

This work is licensed under a

Creative Commons Attribution 4.0

License.

Publisher:

Scientific Publishing Institute

Received: 7 May 2020

Revised: 15 June 2020

Accepted: 26 June 2020

Published: 29 July 2020

Funding: This study received no specific financial support.

Competing Interests: The authors declare that they have no competing interests.

\section{Introduction}

A FGN is based on the financial instruments, institutions, and market within a state that raised the effect of enforcement, transaction cost and information on the economy (Cevik \& Rahmati, 2020; Ehigiamusoe \& Lean, 2018; Hobelsberger, 2020). In Brazil, the state is quite stable to maintain its financial position in the diverse global market. Like, when its inflation rate is considered in the last few months, then it comes to the knowledge that there is a great fluctuation faced from the end of 2019 and the beginning of 2020, due to the occurrence of coronavirus pandemic at an international and national forum. But its government is quite efficient to control this situation gradually (Brazil Inflation Rate, 2020) as shown in the following graph; 


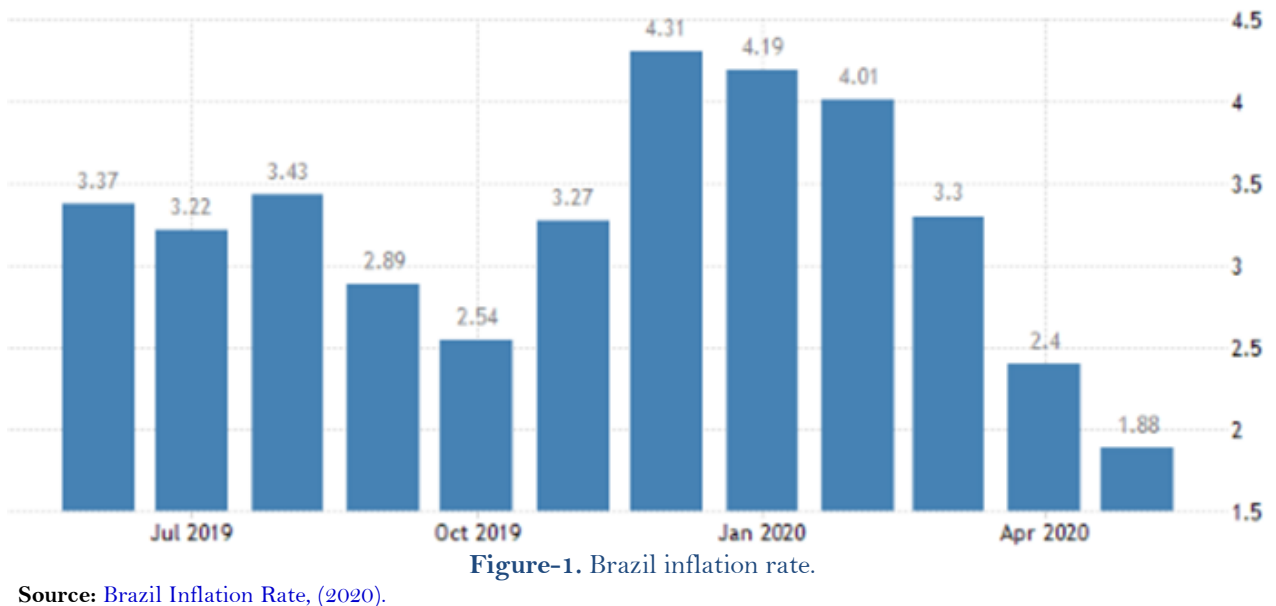

After considering the above graph, it becomes clear that its financial planners have a broader view of the finance-growth nexus. Well, in its previous years' performance, its economic growth rate was increased from 2014 to 2018 (Brazil GDP Growth Rate1961-2020, 2020).

Growth theory is witnessed as a rival in the development of the endogenous growth model in the second half of the 1980s and 1990s. This theoretical approach has a long way towards accounting for a phenomenon linked with economic development in the United States. This economic theory based models majorly presented to address all those factors that emphasize the role of technological progress as a catalyst for the economic transformation within a state. This growth theory helps the state's authorities to develop such strategies that fulfil the need of the private sector business, trading and domestic saving within a state. According to the previous scholars, this theoretical approach enhanced the direct relationship between economic growth and the bank concentration by developing an imperfect competition within a banking system. Because this theory predicts that whenever a company reached to a sufficient level of financial development, then a financial institutions' concentration cause a negative impact on economic growth development (Diallo \& Koch, 2018). Also, Nawaz and Hassan (2016) and others considered this growth theory influence on the linkage between tourism development, renewable energy consumption and EG in the developed states; where their outcomes depict that economic growth and tourism development are interdependent in Germany, while inverse outcome occurred in Spain perspective. But in China and Turkey, the tourism enhancements directly impact on the state's growth. It means this theory having different implications in the states' economies based on their demographics (Isik, Dogru, \& Turk, 2018).

To explore the importance of credit to the private sector for the economic growth of a state, a research was conducted by different scholars in their Internet and Banking and Commerce based Journal, where they strategically considered the financial inclusion for the development and growth of economic status of a Nigeria over the period 1986-2015 by using an ordinary least square technique. After measuring the financial deepening indicators like a loan to deposit ratio and branch network, they concluded that the private sector credit productively influence on the GDP growth of a state because of increasing the circulation of money (Okoye, Erin, \& Modebe, 2017). In 2017, somehow similar topic research was conducted by an economist who worked on the case study of Bangladesh. According to them, such private-sector development results in the long term economic growth of a state and will ensure the smooth operation of both primary and secondary market, minimizing the market's volatility, enhanced the financial literacy among investors, promote entrepreneurial projects initiate knowledge-based trading, generating more professional trustee and ensure the authenticate credit rating from the rating agencies (Banerjee, Ahmed, \& Hossain, 2017).

In the Asian Journal of Economic Modelling, important research made by Nhung Thi Kim on considering the impact of domestic savings in the EG of Vietnam. In her research, she critically evaluated both long term and short term perspectives of these major variables and focused on dependency and accounting for domestic investment ratio. According to their short-run estimation, the dependency ratio, domestic savings and domestic investment do not majorly impact on EG, but in long term estimation, the domestic saving and its investment positively boost the economic growth, but dependency ratio shows the opposite outcome again (Kim \& Nguyen, 2017). In the same year, other related field scholars conducted empirical research on examining the causality direction between the GDS and economic growth among the six sub-Sahara African states. According to these scholars, there is unidirectional causality from the EG to GDS for Burkina and Ghana, while the GDS causes EG in the Niger, Liberia and Sierra Leone (Bolarinwa \& Obembe, 2017). Well, Hussain and Slepov in their different articles on the same topic justified this point that domestic saving causes a major impact on the GDP growth of a state because if its saving rate becomes much higher than the overall state's circulation of money, then it results in the decrease of economic activities. So, being an economist, it will be quite favorable for the state's sustainability to stabilize the domestic saving in that state which cause a productive impact on enhancing their economic development in both long and short run (Hussain et al., 2017; 
Slepov et al., 2017). These scholars conducted a comparative study between the developing states and concluded that their economies are highly affected due to the higher gross domestic saving.

TO is such typical topic which majorly focused by a large number of scholars by considering its impact on the economic growth of a state like Jamilah Idris and others in their Business and Society based International Journal stated that TO is one of the major drivers to simulate the growth within a state. They majorly studied 87 states includes both Organizational for Economic Co-operation and Development (OECD) and the other developing nations. Their empirical study concluded that there is a causal relationship between the trade openness and growth in the panel wise analysis like if this openness is increased then higher growth will be seen (Idris, Yusop, \& Habibullah, 2016). In 2015, Mohammad Salauddin and Jeff Gow majorly investigate the relationship among EG, financial development and internet use by considering the rapid usage of the internet in the last few years in South Africa. According to them, the internet use and financial development directly enhanced the economic growth of a state (Salahuddin \& Gow, 2016; Shittu, Hassan, \& Nawaz, 2018). According to Economic Studies, the researchers conducted the panel data-based analysis to investigate the impact of TO, environmental quality, and population growth on the EG of a developed and developing state. In the end, they concluded that there is a relationship between the TO and the EG, and the unidirectional relation among the trade openness and the $\mathrm{CO} 2$ emission in the developed states (Rahman, Saidi, \& Mbarek, 2017). In addition to this, the other related scholars stated that such trade openness based attractive policy directly enhanced the import and export rate by developing a fruitful relationship within the states. According to them, such favorable relationships result in motivating the international investors to invest in the economic projects of the state and enhanced the economic state of the domestic market (Dritsakis \& Stamatiou, 2016; Malefane, 2018). This shows that if the developing nation worked on upgrading the trade policies by encouraging the other states' investors to enter the domestic market, then there will be more chances to earn a huge amount of per capita income within a state.

The problem statement of this paper is to make an informative research on considering the gross domestic, credit to private sector and trade openness factors and their influence on the economic development of the state. This topic will help to ensure the finance-growth nexus of a state by controlling its inflation rate. The major aims of this research paper are;

- To inspect the impact of credit to the private sector on the economic growth (EG) of Brazil.

- To inspect the impact of gross domestic saving (GDS) on the economic growth (EG) of Brazil.

- To inspect the impact of trade openness (TO) on the economic growth (EG) of Brazil.

In the previous literature, many scholars evaluate the concept of finance-growth nexus by considering the role of banks, its influence on public institutions, and other emerging state's data (Nyasha \& Odhiambo, 2018; Silva, Tabak, \& Laiz, 2019). Also, there was important research made by Bist and Bista on considering the FGN in Nepal by focusing on the ARDL approach application in the statistical analysis (Bist \& Bista, 2018). After analyzing the scholar's data on the related topic, it becomes clear that nobody majorly focused on the economy of Brazil as a case study of this finance-growth nexus, which is majorly focused in this research paper. This paper will be based on valid data of the Brazil market.

This data will be utilized by the Brazil administration, policymakers and the business community to understand the influence of trade openness, private sector development and the domestic saving on the advanced economic growth of this state. Overall, it will be challenging research that will give a new direction to the future researchers to understand the macroeconomic factor that directly impacts on the national GDP growth. Also, this data can be utilized by the local natives of this state to understand their responsibility towards economic growth. As this section one is based on providing a brief introduction of all this research topic, its problem statement, objectives, justification and significance, so the next section will be based on literature review. In this section two, research methodology, there will be a description of the method of this research. After this, the result and analysis based section three will be based on providing the statistical values of the tested variable, and section four of discussion and conclusion will explore all the empirical outcomes in the Brazil economic situation and conclude all the information. Also, the limitations and future implications of this study will be discussed in this section.

\section{Methodology}

2.1. Selection and Measurement of Variables

The purpose to conduct the current study is to discover the relationship among financial development and economic growth of Brazil, which is clear from the title of the study i.e. finance-growth nexus. In the literature, there are various indicators that have been employed by the researchers to compute the financial development of a country. Some of them include monetary aggregates as well as narrow and broad money supply, bank deposit liabilities, financial development index etc. The researchers have argued that credit to private sector can be used as a high-quality indicator measure the financial development as it clearly depicts the transfer of funds between savers and borrowers. In addition, the credit of private sector just involves the private sector and excludes all the other sectors such as government and public sector (Beck, Levine, \& Loayza, 2000). Therefore, this aspect can be used as a significant variable in the current study. In addition to credit to private sector, further variables such as gross domestic saving, inflation and trade openness have also 
been used in the current study in association with economic growth. Other than, these there might be other variables as well that could be taken to study the finance growth nexus but the variables taken in the current study have major and crucial impact on financial development as well as economic growth. It has also been argued in the past studies that saving is the aspect due to which the economic growth is impacted by the financial development. Similarly, trade openness enhances the chances of innovation in technology in the countries where trade is taking place. Similarly, inflation aspect influences both the financial development and economic growth by having an impact on the interest rate in financial firms. In the last, economic growth has been taken as the GDP of the country.

\subsection{Data and Model Specification}

As discussed earlier, the current study is designed to investigate the "finance-growth nexus" in Brazil. Therefore, the researcher has collected data from Brazil and the collected data is time series. The period for which the data has been gathered comprises of 30 years and has been collected from the most authentic sources of data or databases such as World Bank Development Indicators as suggested by the earlier studies in similar context (Christopoulos \& Tsionas, 2004). The estimated Equation 1 can be presented as follows;

\section{$G D P_{t}=\alpha+\beta_{1} P R V T_{t}+\beta_{2}$ GDS $_{t}+\beta_{3} O P E_{t}+\beta_{4} I N F_{t}+\varepsilon_{t}$}

In the similar way, as the casual relationship is not very clear as far as finance growth nexus is concerned, therefore in order to find out the casualty, the following equation has also been developed based on a past study (Christopoulos \& Tsionas, 2004).

\section{$P R V T_{t}=\alpha+\beta_{1} G D P_{t}+\beta_{2} G D S_{t}+\beta_{3} O P E_{t}+\beta_{4} I N F_{t}+\varepsilon_{t}$}

In these long run or equilibrium equations, GDP represents the economic growth which is calculated as the \% change in GDP of a country. PVRT represents the credit to private sector and it is measured through the percentage of GDP. In the same way, GDS shows the gross domestic savings which has also been measured through the percentage of GDP. Moreover, OPE represents trade openness in a country involving both imports and exports and finally INF is showing the inflation rate of a country and is measured through the percentage change in "consumer price index CPI". The $\varepsilon_{t}$ in the equations is representing the error terms.

\subsection{Estimation Procedure}

As the researcher has used ARDL framework in the current study which does not have the requirement to check for the order of integration regarding the variables if they are of zero order or first order. However, it must be noted that ARDL approach does not provide accurate results if the variables possess second order of integration (Pesaran, Shin, \& Smith, 2001). This is the reason why the researcher has applied two natures of unit root tests i.e. ADF and PP unit root tests to make sure that the variables of the study are not having second order integration. After the identification of the order of integration associated with the variables of the study, the subsequent step was to find out the cointegrated relationships between the variables. For this purpose, the researcher has applied the ARDL approach of cointegration so that the long run relationships present among the variables of the study can be explored. A dummy variable has also been added into the ARDL model so that the break points can be recognized in the collected time series data. The following equations must be considered in this regard,

$$
\begin{aligned}
\Delta G D P_{t}=\alpha+ & \sum_{j=1}^{p} \lambda_{1 i} \mathrm{GDP}_{t-1}+\sum_{j=0}^{q} \lambda_{2 i} \Delta P R V T_{t-1}+\sum_{k=0}^{r} \lambda_{3 i} \Delta G D S_{t-1}+\sum_{u=0}^{m} \lambda_{4 i} \Delta O P E_{t-1} \\
& +\sum_{v=0}^{n} \lambda_{5 i} \Delta I N F_{t-1}+\delta_{1} G D P_{t-1}+\delta_{2} P R V T_{t-1}+\delta_{3} G D S_{t-1}+\delta_{4} O P E_{t-1}+\delta_{5} I N F_{t-1} \\
& +\delta_{6} D_{G D P}+e_{t} \\
\Delta P R V T_{t}=\theta+ & \sum_{i=1}^{p} \beta_{1 i} \Delta P R V T_{t-1}+\sum_{j=0}^{q} \beta_{2 i} \Delta G D P_{t-1}+\sum_{k=0}^{r} \beta_{3 i} \Delta G D S_{t-1}+\sum_{u=0}^{m} \beta_{4 i} \Delta O P E_{t-1} \\
& +\sum_{v=0}^{n} \beta_{5 i} \Delta I N F_{t-1}+\gamma_{1} P R V T_{t-1}+\gamma_{2} G D P_{t-1}+\gamma_{3} G D S_{t-1}+\gamma_{4} O P E_{t-1}+\gamma_{5} I N F_{t-1} \\
& +\gamma_{6} D_{P R V T}+e_{t}
\end{aligned}
$$

In these equations, D has been used as a dummy variable to cater the "structural breaks". In addition, the $\beta$ and $\gamma$ are representing the coefficients of the variables. Moreover, $p, q, r, m$ and $n$ are showing the lagged numbers derived on the basis of SIC. Finally the bound testing has been used to examine the long run relationships linking the variables through $\mathrm{F}$ test significance. In this regard, the upper and lower bounds values are judged against the $\mathrm{F}$ value and on this basis the null hypothesis fails to be accepted and accepted. If $\mathrm{F}$ value is above the upper bound, the null hypothesis is considered rejected and if it is less than lower bound 
then it will be accepted. If it is stuck amid upper and lower bound, the result will be ambiguous. In the end, the researcher has used Granger Casualty test in the current study through VECM as it assists the researcher to evaluate long run plus short run casualty among the variables (Engle \& Granger, 1987).

\section{Results Analysis}

As discussed earlier, the researcher has applied the ADF and PP unit root tests so that it can be made sure that none of the variables of the study are having the second order cointegration as it might result in nonapplicability of ARDL approach. The results of both unit root tests are presented in the Table 2. In case of ADF test, it can be perceived that in the level section, only one variable, trade openness has not accepted the null hypothesis and in the first difference section, all the variables of the study have rejected the null hypothesis of unit root. Therefore, it can be indicated that all the variables are having either zero or first order integration. In the same way, in context of PP unit root test, in level series, the null hypothesis is rejected only by one variable, inflation. On the contrary, in the first difference series, all the variables have rejected the null hypothesis. In a nutshell, both the tests have proved that no variable is having second order of integration and thus ARDL approach can be applied to the data collected.

Table-2. Unit root test.

\begin{tabular}{|c|c|c|c|c|}
\hline \multirow[b]{2}{*}{ Variable } & \multicolumn{2}{|c|}{ ADF Test } & \multicolumn{2}{|c|}{ PP Test } \\
\hline & Level & $1^{\text {st }}$ Difference & Level & $1^{\text {st }}$ Difference \\
\hline GDP & $\begin{array}{c}-4.8264 \\
(0.732)\end{array}$ & $\begin{array}{c}-9.2461^{* * * *} \\
(0.000)\end{array}$ & $\begin{array}{l}-3.6153 \\
(0.234)\end{array}$ & $\begin{array}{c}-11.2565^{* * *} \\
(0.000)\end{array}$ \\
\hline PRVT & $\begin{array}{c}-2.2743 \\
(0.253)\end{array}$ & $\begin{array}{c}-5.8721^{* *} \\
(0.000)\end{array}$ & $\begin{array}{l}-0.8163 \\
(0.232)\end{array}$ & $\begin{array}{c}-7.0872^{* *} \\
(0.000)\end{array}$ \\
\hline GDS & $\begin{array}{r}-5.8242 \\
(0.374)\end{array}$ & $\begin{array}{c}-12.2632^{* * * *} \\
(0.000)\end{array}$ & $\begin{array}{l}-3.6153 \\
(0.561)\end{array}$ & $\begin{array}{c}-14.9972 * * * \\
(0.000)\end{array}$ \\
\hline OPE & $\begin{array}{c}-3.6164^{*} \\
(0.042)\end{array}$ & $\begin{array}{c}-7.1863^{* * * *} \\
(0.000)\end{array}$ & $\begin{array}{c}-1.7352 \\
(0.234)\end{array}$ & $\begin{array}{c}-10.2532^{* * *} \\
(0.000)\end{array}$ \\
\hline INF & $\begin{array}{c}-6.9133 \\
(0.416)\end{array}$ & $\begin{array}{c}-11.3746^{* * *} \\
(0.000)\end{array}$ & $\begin{array}{l}-4.7524^{*} \\
(0.0275)\end{array}$ & $\begin{array}{c}-13.7772^{* *} \\
(0.000)\end{array}$ \\
\hline
\end{tabular}

After the identification of the order of integration through the unit root tests, the next test applied was bounds cointegration test. The results of bound testing have been presented in the Table 3 of the study. The table makes it quite clear that in case of economic growth GDP, the F statistic value 28.73 is high as comparison to the upper bound value at $1 \%$ significance level. In the exact opposite manner, in case of private credit, the $\mathrm{F}$ statistics value 3.545 is lower to the upper bound value. The comparison of these values points toward that there is cointegration among the variables in case of GDP while no cointegration has been found in case of private credit or financial development. This also suggests that there is "unidirectional casual relationship" whose direction is from financial development towards the direction of economic growth.

Table-3. Bounds testing.

\begin{tabular}{|c|c|c|c|c|}
\hline \multicolumn{2}{|l|}{ Variables } & ARDL & F-Statistics & Outcome \\
\hline \multicolumn{5}{|c|}{ Economic Growth GDP } \\
\hline Regressor: PRI & T, GDS, OPE, INF, and $\mathrm{D}_{\mathrm{GDP}}$ & $(1,0,0,1,1)$ & $28.73^{* * *}$ & Cointegration \\
\hline \multicolumn{5}{|c|}{ Private Credit } \\
\hline \multicolumn{2}{|c|}{ Regressor: GDP, GDS, OPE, INF, and DPRVT } & $(1,0,0,0,0)$ & 3.545 & No Cointegration \\
\hline \multirow[t]{3}{*}{ Critical Values } & \begin{tabular}{|c|}
$1 \%$ \\
\end{tabular} & \begin{tabular}{l|l}
$1 \%$ & \\
\end{tabular} & $5 \%$ & $5 \%$ \\
\hline & Lower & Upper & Lower & Upper \\
\hline & 3.74 & 5.06 & 2.86 & 4.01 \\
\hline
\end{tabular}

The results of long run ARDL estimation have been reported in the Table 4 of the study. According to these results, the private credit has significant and constructive impact on the economic growth of Brazil. In other words, the economic growth of Brazil is expected to increase by $8.6 \%$ with one percent increase in the credit towards private sector. In the same way, it can be derived from the table that savings does not have the significant impact upon economic growth in long run in Brazil. However, the shock of trade openness has been found as negative and significant towards the economic growth. It can be stated that with one percent enhance in trade openness, the economic growth might be decreased by $7.4 \%$ in Brazil. In the exact similar fashion, inflation has also posed negative along with significant impact on the economic growth in Brazil. In other words, if the inflation in enhanced by one percent, then in Brazil, the economic growth might fall by $15.4 \%$. In addition to these results, it can also be estimated from the diagnostics statistics that there are no errors in the obtained results and the results are stable and serially independent. 


\begin{tabular}{|c|c|}
\hline Variable & GDP \\
\hline \multirow[t]{2}{*}{ PRVT } & $0.086^{* * *}$ \\
\hline & {$[0.023]$} \\
\hline \multirow[t]{2}{*}{ GDS } & -0.076 \\
\hline & {$[0.342]$} \\
\hline \multirow[t]{2}{*}{ OPE } & $-0.074 * *$ \\
\hline & {$[0.012]$} \\
\hline \multirow[t]{2}{*}{ INF } & $-0.154^{*}$ \\
\hline & {$[0.045]$} \\
\hline \multirow[t]{2}{*}{$\mathrm{D}_{\mathrm{GDP}}$} & $-1.743^{* *}$ \\
\hline & {$[0.032]$} \\
\hline \multirow[t]{2}{*}{ Constant } & 6.865 \\
\hline & {$[0.000]$} \\
\hline R-Bar-Squared & 0.6325 \\
\hline \multirow[t]{2}{*}{ F-Stat } & $8.643^{* * *}$ \\
\hline & {$[0.000]$} \\
\hline \multirow[t]{2}{*}{ Jarque-Bera JB Test } & 0.747 \\
\hline & {$[0.7558]$} \\
\hline \multirow[t]{2}{*}{ Lagrange Multiplier } & 0.964 \\
\hline & {$[0.7467]$} \\
\hline \multirow[t]{2}{*}{ Ramsey Test } & 0.256 \\
\hline & {$[0.9321]$} \\
\hline
\end{tabular}

In short run estimation, the results have been presented in the Table 5. These results suggest that the private credit has significant and constructive impact on the economic growth of Brazil in short run. It can be said that the economic growth of Brazil is expected to increase by $79.6 \%$ with one percent boost in the credit to private sector. In the same way, it can be indicated from the table that gross domestic savings does not have the significant impact on economic growth in longer run in Brazil. However, the impact by trade openness has been found as negative along with significant towards the economic growth. It can be stated that with one percent boost in trade openness, the economic growth might fall by $27.4 \%$ in Brazil. Contrarily, inflation has insignificant impact towards the economic growth in Brazil.

Table-5. ARDL short run estimation.

\begin{tabular}{c|c}
\hline Variable & $\Delta$ GDP \\
\hline$\Delta$ PRVT & $0.796^{* *}$ \\
\hline$\Delta \mathrm{GDS}$ & {$[0.013]$} \\
\hline$\Delta \mathrm{OPE}$ & -0.236 \\
\hline$\Delta \mathrm{INF}$ & {$[0.142]$} \\
\hline & $-0.274^{* *}$ \\
\hline$\Delta \mathrm{D}_{\mathrm{GDP}}$ & {$[0.032]$} \\
\hline & -0.074 \\
\hline $\mathrm{ECT}_{\mathrm{t}-1}$ & {$[0.245]$} \\
\hline & $-2.753^{* *}$ \\
\hline & {$[0.012]$} \\
\hline & $2.545^{* * *}$ \\
\hline
\end{tabular}

The CUSUM and CUSUMSQ plots for the economic growth model have been shown in the Figure 2. According to these plots, it is quite evident that both the plots are within the critical range and it suggests that the models of the study are stable over the period of time. 


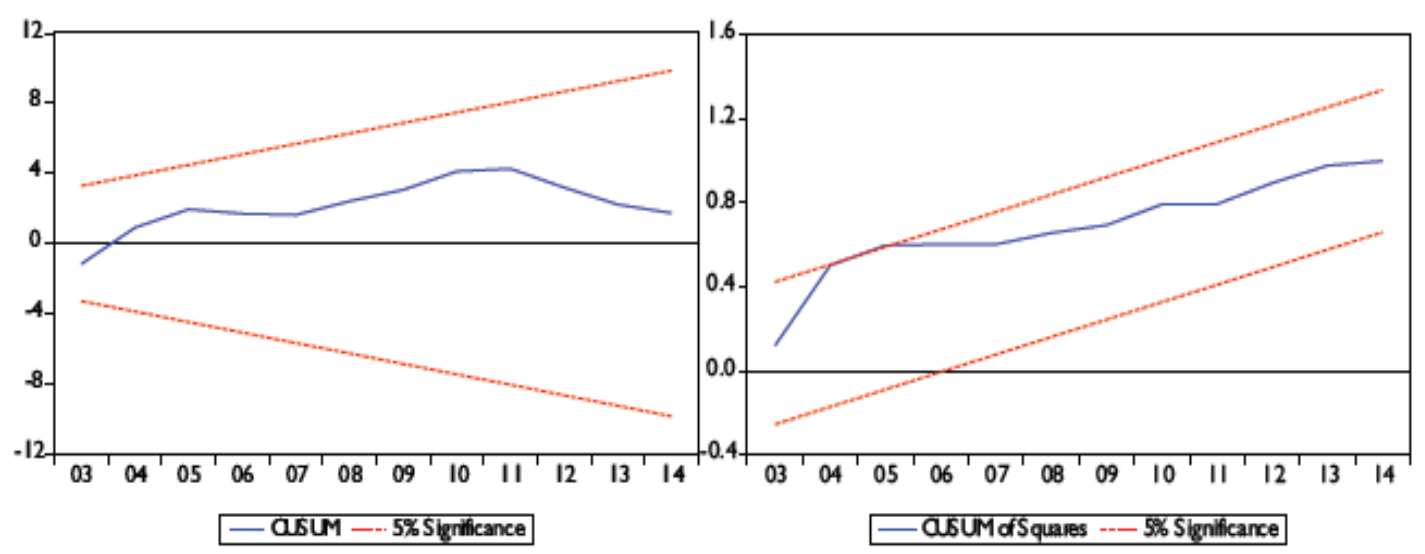

Figure-2. CUSUM and CUSUMSQ Plots.

\section{Discussion and Conclusion}

\subsection{Discussion}

The Purpose to conduct the current study was to explore the impact casted by private credit, trade openness, inflation and GDS on the GDP of Brazil. In this regard, the researcher collected time series data from Brazil for 30 years regarding the aforementioned variables and applied ARDL approach of estimation both for longer run along with shorter run and the results were obtained. The results have suggested that private credit has significant along with positive impact on economic growth both in long run and short run. In other words, if the flow of credits towards the private sector is greater then it will results in the growth along with development of economy of the country. This result is in consistency with the similar past studies (Arestis \& Baltar, 2019; Muhammad, Islam, \& Marashdeh, 2016). The next result by researcher suggest that gross domestic saving does not pose any significant impact on the GDP of the country in longer run along with shorter run. This might be due to the reason that the savings are not effectively utilized in order to make innovations in the technology of the country thus having no impact on the economy. This result is in accordance with the past studies regarding finance growth nexus (Aghion, Comin, Howitt, \& Tecu, 2016; Kashif, Sridharan, \& Thiyagarajan, 2017). Moreover, the impact of trade openness has been found as significant along with negative in Brazil. This might be due to the unfavorable policies regarding trade in the country due to which trade openness impacts negatively on the economic growth. This result is parallel to the past studies conducted for the same purpose (Pant, 2005). Another important result is that the inflation has significant and negative shock on economic growth in long run; although this impact is insignificant in short run. In other words, if the condition of inflation prevails for a longer period of time, it will negatively impact the GDP and development. This result is in concordance with the literature of similar context (Yanikkaya, $2003)$.

\subsection{Conclusion}

In Continuation of the goal of the current study i.e. to explore the relationship amid financial development and GDP of Brazil, the results obtained from the analysis of the composed data suggest that the results have suggested that private credit has significant along with positive impact on GDP. The next result proves that gross domestic saving does not pose any major impact on the GDP of the country. The impact of trade openness has been found as significant along with negative in Brazil. The inflation has significant along with negative impact on GDP in longer run but this impact is not visible in short run. Thus it can be concluded on the basis of these results that Brazil must increase the flow of credit towards private sector. In addition, the policies regarding trade in the country must also be revised and must be made favorable. In addition, the inflation must be controlled in the longer run in the country in order to enhance the GDP of the country.

\subsection{Implications and Limitations}

The current study has major practical implications for the government and policy makers of Brazil. They might get guidance by the results of the current study in such a way that they might consider increasing the flow of credit towards private sector. In addition, the policies regarding trade in the country might also be revised and must be made favorable. In addition, the inflation is also supposed to be controlled in the longer run in the country in order to enhance the GDP of the country. Furthermore, this study might contain benefits for the researchers as they may use the literature and the results of the study for their research purposes and may also consider improving it in future. They should increase the size of the sample by collecting data for more than 30 years and may also use some other tests for analysis of time series type data in future. 
References

Aghion, P., Comin, D., Howitt, P., \& Tecu, I. (2016). When does domestic savings matter for economic growth? IMF Economic Review, 64(3), 381-407.Available at: https://doi.org/10.1057/imfer.2015.41.

Arestis, P., \& Baltar, C. T. (2019). A model of economic growth for an open emerging country: Empirical evidence for Brazil. Structural Change and Economic Dynamics, 49(6), 217-227.Available at: https://doi.org/10.1016/j.strueco.2018.10.005.

Banerjee, P. K., Ahmed, M. N., \& Hossain, M. M. (2017). Bank, stock market and economic growth: Bangladesh perspective. The Journal of Developing Areas, 51(2), 17-29.Available at: https://doi.org/10.1353/jda.2017.0028.

Beck, T., Levine, R., \& Loayza, N. (2000). Finance and the sources of growth. Journal of Financial Economics, 58(1-2), 261300.

Bist, J. P., \& Bista, N. B. (2018). Finance-growth nexus in Nepal: An application of the ARDL approach in the presence of structural breaks. Vikalpa, 43(4), 236-249.Available at: https://doi.org/10.1177/0256090918813211.

Bolarinwa, S. T., \& Obembe, O. B. (2017). Empirical analysis of the nexus between saving and economic growth in selected African countries (1981-2014). Journal of Development Policy and Practice, 2(1), 110-129.Available at: https://doi.org/10.1177/2455133316676420.

Brazil GDP Growth Rate1961-2020. (2020). Macrtrends.com. Retrieved from: https://www.macrotrends.net/countries/BRA/brazil/gdp-growth-rate.

Brazil Inflation Rate. (2020). Trading economics.com. Retrieved from: https://tradingeconomics.com/brazil/inflation-cpi.

Cevik, S., \& Rahmati, M. H. (2020). Searching for the finance-growth nexus in Libya. Empirical Economics, 58(2), 567581.Available at: https://doi.org/10.1007/s00181-018-1593-6.

Christopoulos, D. K., \& Tsionas, E. G. (2004). Financial development and economic growth: Evidence from panel unit root and cointegration tests. Journal of development Economics, 73(1), 55-74.Available at: https://doi.org/10.1016/j.jdeveco.2003.03.002.

Diallo, B., \& Koch, W. (2018). Bank concentration and Schumpeterian growth: Theory and international evidence. Review of Economics and Statistics, $100(3), 489-501$.Available at: https://doi.org/10.1 162/rest_a_00679.

Dritsakis, N., \& Stamatiou, P. (2016). Trade openness and economic growth: A panel cointegration and causality analysis for the newest EU countries. Romanian Economic Journal, 18(59), 45-60.

Ehigiamusoe, K. U., \& Lean, H. H. (2018). Finance-growth nexus: New insights from the West African region. Emerging Markets Finance and Trade, 54(1 1), 2596-2613.Available at: https://doi.org/10.1080/1540496x.2017.1364623.

Engle, R. F., \& Granger, C. W. (1987). Co-integration and error correction: Representation, estimation, and testing. Econometrica: Journal of the Econometric Society, 55(2), 251-276.Available at: https://doi.org/10.2307/1913236.

Hobelsberger, K. (2020). An empirical re-assessment of the finance-growth nexus.

Hussain, I., Khan, Z., Khan, M. I., Khalid, S., Kiran, A., \& Hussain, T. (2017). Long run and short run relationship among gross domestic saving, net bilateral foreign aid, external debt and economic growth in Pakistan. Dynamics of Economics, 1(1), 1-7.

Idris, J., Yusop, Z., \& Habibullah, M. S. (2016). Trade openness and economic growth: A causality test in panel perspective. International Journal of Business and Society, 17(2), 281-290.

Isik, C., Dogru, T., \& Turk, E. S. (2018). A nexus of linear and non-linear relationships between tourism demand, renewable energy consumption, and economic growth: Theory and evidence. International Journal of Tourism Research, 20(1), 38-49.Available at: https://doi.org/10.1002/jtr.2151.

Kashif, M., Sridharan, P., \& Thiyagarajan, S. (2017). Impact of economic growth on international reserve holdings in Brazil. Brazilian Journal of Political Economy, 37(3), 605-614.Available at: https://doi.org/10.1590/0101$31572017 \mathrm{v} 37$ n03a08.

Kim, N. T., \& Nguyen, H. H. (2017). Impacts of domestic savings on economic growth of Vietnam. Asian Journal of Economic Modelling, 5(3), 245-252.Available at: https://doi.org/10.18488/journal.8.2017.53.245.252.

Malefane, M. R. (2018). Impact of trade openness on economic growth: Empirical evidence from South Africa.

Muhammad, N., Islam, A. R. M., \& Marashdeh, H. A. (2016). Financial development and economic growth: An empirical evidence from the GCC countries using static and dynamic panel data. Journal of Economics and Finance, 4O(4), 773-791.Available at: https://doi.org/10.1007/s12197-015-9331-9.

Nawaz, M. A., \& Hassan, S. (2016). Investment and tourism: Insights from the literature. Journal of Economic \& Management Perspectives, $10(4), 581-590$.

Nyasha, S., \& Odhiambo, N. M. (2018). Finance-growth nexus revisited: Empirical evidence from six countries. Scientific Annals of Economics and Business, 65(3), 247-268.Available at: https://doi.org/10.2478/saeb-2018-0021.

Okoye, L. U., Erin, O., \& Modebe, N. J. (2017). Financial inclusion as a strategy for enhanced economic growth and development. The Journal of Internet Banking and Commerce, 1-14.

Pant, B. (2005). Nepal's trade sector: Review, repercussions and recommendations. Economic Review, 17, 89-115.

Pesaran, M. H., Shin, Y., \& Smith, R. J. (2001). Bounds testing approaches to the analysis of level relationships. Journal of Applied Econometrics, 16(3), 289-326.Available at: https://doi.org/10.1002/jae.616.

Rahman, M. M., Saidi, K., \& Mbarek, M. B. (2017). The effects of population growth, environmental quality and trade openness on economic growth: A panel data application. Journal of Economic Studies, 44(3), 456-474.Available at: https://doi.org/10.1108/jes-02-2016-0031.

Salahuddin, M., \& Gow, J. (2016). The effects of Internet usage, financial development and trade openness on economic growth in South Africa: A time series analysis. Telematics and Informatics, 33(4), 1141-1154.Available at: https://doi.org/10.1016/j.tele.2015.11.006.

Shittu, W. O., Hassan, S., \& Nawaz, M. A. (2018). The nexus between external debt, corruption and economic growth: Evidence from five SSA countries. African Journal of Economic and Management Studies, 9(3), 319-334.Available at: https://doi.org/10.1108/ajems-07-2017-0171.

Silva, T., Tabak, B., \& Laiz, M. (2019). The finance-growth nexus: The role of banks. 
Slepov, V., Burlachkov, V., Danko, T., Kosov, M., Volkov, I., Grishina, O., \& Sekerin, V. (2017). The country's economic growth models and the potential for budgetary, monetary and private financing of gross domestic product growth. 20(4), 488-500.

Yanikkaya, H. (2003). Trade openness and economic growth: A cross-country empirical investigation. Journal of Development Economics, 72(1), 57-89.Available at: https://doi.org/10.1016/s0304-3878(03)00068-3. 